\title{
PENGATURAN PENYELESAIAN SENGKETA DALAM SISTEM PEER TO PEER LENDING
}

\author{
Luh Sarini, Peradi Cabang Denpasar, e-mail: niluhsarini@yahoo.com \\ Putu Devi Yustisia Utami, Fakultas Hukum Universitas Udayana, e-mail: \\ deviyustisia@unud.ac.id
}

doi: https://doi.org/10.24843/KS.2020.v09.i01.p05

\begin{abstract}
ABSTRAK
Penelitian ini mempunyai tujuan untuk memahami hubungan setiap pihak pada sistem Peer to Peer Lending secara hukum serta menganalisis pengaturan penyelesaian sengketa pada sistem Peer to Peer Lending. Metode pada penelitian ini yaitu penelitian yuridis normatif dengan mempergunakan pendekatan perundang-undangan dalam menganalisis isu hukum yang sumber hukumnya berasal dari bahan hukum primer, sekunder, serta tersier. Hasil pada penulisan ini menunjukkan bahwa belum terdapat pengaturan secara khusus terkait penyelesaian sengketa dalam sistem Peer to Peer Lending. Sengketa pada sistem tersebut membutuhkan proses penyelesaian sengketa yang cepat, mudah, serta terjangkau sehingga perlu dibentuk Lembaga Alternatif Penyelesaian Sengketa online yang khususnya menangani sengketa bisnis dengan sistem Peer to Peer Lending.
\end{abstract}

Kata Kunci: Penyelesaian Sengketa, Peer to Peer Lending

\begin{abstract}
This study aims to understand the relationship of each party in the Peer to Peer Lending system legally and to analyze dispute resolution arrangements in the Peer to Peer Lending system. The method in this research is normative juridical research using a statutory approach in analyzing legal issues whose sources of law come from primary, secondary and tertiary legal materials. The results of this paper indicate that there is no specific arrangement regarding dispute resolution in the Peer to Peer Lending system. Disputes in this system require a dispute resolution process that is fast, easy, and affordable, so it is necessary to establish an alternative online Dispute Resolution Institute which specifically handles business disputes with the Peer to Peer Lending system.
\end{abstract}

\section{Key Words: Dispute Resolution, Peer to Peer Lending}

\section{Pendahuluan}

\subsection{Latar Belakang Masalah}

Berkembangnya teknologi informasi, terutama berkaitan dengan internet memacu pertumbuhan bisnis secara daring yang lebih dikenal dengan istilah bisnis online dan kegiatan perdagangan secara elektronik atau biasa disebut e-commerce. Dewasa ini segala aktivitas dilakukan berbasis online baik dalam melaksanakan kegiatan penjualan, pembelian serta pembayaran. Perubahan gaya hidup modern di era ini akhirnya menimbulkan style bisnis baru yaitu pinjam meminjam uang dengan teknologi informasi yang lebih dikenal dengan istilah Peer To Peer Lending (selanjutnya disebut P2P Lending). Oleh karena adanya kemudahan berupa syarat agunan yang fleksibel, luas jangkauan, dan kemudahan lainnya, maka P2P Lending merupakan pilihan sumber pendanaan baru bagi masyarakat jika dibandingkan dengan sumber lain seperti institusi perbankan, maupun badan hukum koperasi yang prosesnya tidak sesederhana $P 2 P$ 


\section{Lending. ${ }^{1}$}

Definisi bisnis sebenarnya lebih luas dibanding definisi perdagangan, hal ini dikarenakan cakupan aktivitas bisnis tidak hanya tentang perdagangan namun, mencakup hal yang lebih besar meliputi produksi hingga pemasaran, pengadaan barang/jasa, jasa konsultasi bisnis, jasa rekrutmen tenaga kerja, perkreditan, asuransi, penjaminan kredit, media massa, kerja sama usaha, investasi, properti, serta yang lainnya. ${ }^{2}$ Aktivitas bisnis yang dilaksanakan mempergunakan sarana elektronik disebut dengan $e$-business, sedangkan perdagangan yang dilaksanakan mempergunakan sistem elektronik disebut $e$-commerce. ${ }^{3}$

Baik e-business maupun e-commerce memiliki keterkaitan dengan transaksi elektronik yakni transaksi yang mempergunakan media elektronik. Lain dengan transaksi pembayaran, transaksi elektronik memiliki arti yang lebih luas, hal itu dikarenakan transaksi ini memiliki kaitan dengan tindakan penjual serta pembeli dalam hal melaksanakan pencarian, sampai pada penyelesaian yaitu dengan pembayaran oleh pihak yang membeli serta pemberian obyek yang diperjualbelikan oleh pihak yang menjual. Transaksi elektronik wajib didasari pada perjanjian atau kontrak baik yang berbentuk konvensional ataupun $e$-contract. ${ }^{4}$

Maraknya pembelian barang melalui transaksi elektronik melahirkan suatu aplikasi sistem pembayaran online. Selain pembayaran online, para pengguna internet saat ini juga dapat mengakses pinjaman atau kredit secara online melalui peminjaman uang dengan memanfaatkan sistem teknologi informasi. Pengaturan dan pengawasan bisnis pinjam meminjam uang dengan sarana teknologi informasi di Indonesia dilaksanakan oleh dua lembaga negara independen yakni Bank Indonesia (selanjutnya disebut BI) serta Otoritas Jasa Keuangan (selanjutnya disebut OJK). Tugas BI yakni melaksanakan pengaturan serta mengawasi usaha jasa pinjam meminjam uang dengan teknologi informasi yang mengeluarkan aplikasi $e$-wallet atau dompet elektronik. ${ }^{5}$ OJK memiliki tugas untuk mengatur dan melaksanakan pengawasan pada bisnis pinjam dan meminjam uang dengan teknologi informasi di luar moneter dan sistem pembayaran. Pengawasan oleh OJK dilakukan secara berjenjang, yaitu pada waktu sebelum beroperasi dengan mensyaratkan pendaftaran dan pada saat telah beroperasi yaitu pelaporan serta pemeriksaan berkala. ${ }^{6}$

Saat ini OJK telah menerbitkan 2 (dua) kebijakan yang memiliki keterkaitan dengan P2P Lending, antara lain Peraturan Otoritas Jasa Keuangan Nomor 77/ POJK.01/2016 tentang Pinjam Meminjam Uang Berbasis Teknologi Informasi (POJK No. 77/POJK.01-2016) serta Surat Edaran Otoritas Jasa Keuangan Nomor 18/ SEOJK.01/2017 tentang Tata Kelola dan Manajemen Risiko Teknologi Informasi pada Layanan Pinjam Meminjam Uang Berbasis Teknologi Informasi yang disebut SEOJK

1 Heryucha Romana Tampubolon, "Seluk Beluk Peer To Peer Lending Sebagai Wujud Baru Keuangan Di Indonesia", Jurnal Bina Mulia Hukum, 3, No. 2, (2019): 192.

2 Serfiyani, Cita Yustisia, dkk, (2013), Bisnis Online dan Transaksi Elektronik, Jakarta: PT. Gramedia Pustaka Utama, h.9.

3 Ibid.

4 Hariyani, I, (2018), Perlindungan Hukum dan Penyelesaian Sengketa Bisnis Jasa PM-Tekfin, Jurnal Legislasi Indonesia, 14(3), h. 346.

5 Ibid.

6 Ernama Santi, Budiharto, Hendro Saptono, "Pengawasan Otoritas Jasa Keuangan Terhadap Financial Technologi (Peraturan Otoritas Jasa Keuangan Nomor 77/POJK.01/2016)", Diponegoro Law Journal, 6, No. 3, (2017): 19 
No.18/SEOJKL.01-2017. Akan tetapi, peraturan-peraturan itu belum bisa menaungi keperluan para pihak jika nantinya salah satu pihak melakukan wanprestasi. Termasuk belum adanya pengaturan mengenai penyelesaian sengketa pinjam meminjam uang dengan sistem $P 2 P$ Lending.

Penulisan karya ilmiah ini diharapkan dapat berkontribusi dan berperan terhadap penambahan ataupun pengembangan ilmu pengetahuan. Beberapa studi terdahulu yang telah mengkaji mengenai pinjam meminjam dengan system teknologi informasi diantaranya pertama, ditemukan pada tulisan dari Kornelius Benuf, Jurnal Rechtsvinding: Media Pembinaan Hukum Nasional berjudul Urgensi Kebijakan Perlindungan Hukum Terhadap Konsumen Fintech Peer To Peer Lending Akibat Penyebaran Covid 19.7 Kedua, ditemukan pada Jurnal Hukum Islam Ahkam yang ditulis oleh Fajrina Eka Wulandari, berjudul Peer to Peer Lending dalam POJK, PBI, dan Fatwa DSN MUI. ${ }^{8}$ Ketiga yaitu tulisan dari Cheyzya Mega Andhini S.P, dalam jurnal JuristDiction dengan judul Problematika Hukum Pada Peer To Peer Lending Dalam Perspektif Hukum Persaingan Usaha. ${ }^{9}$ Ketiga tulisan diatas memiliki pokok bahasan yang berbeda dengan penelitian ini, dimana penelitian ini memfokuskan pada hubungan hukum para pihak pada sistem $P 2 P$ lending secara hukum serta pengaturan penyelesaian sengketa pada sistem $P 2 P$ lending, sehingga penelitian ini memiliki orisinalitas tersendiri.

\subsection{Rumusan Masalah}

Dengan demikian, penelitian ini akan membahas beberapa permasalahan diantaranya:

1. Bagaimanakah hubungan hukum para pihak pada sistem Peer to Peer $(P 2 P)$ Lending?

2. Bagaimanakah pengaturan penyelesaian sengketa pada sistem Peer to Peer $(P 2 P)$ Lending?

\subsection{Tujuan Penelitian}

Penelitian ini memiliki tujuan untuk memberikan pemahaman mengenai hubungan hukum para pihak pada sistem Peer to Peer (P2P) Lending serta memberikan analisis mengenai pengaturan penyelesaian sengketa pada sistem Peer to Peer (P2P) Lending.

\section{Metode Penelitian}

Penulisan karya ilmiah ini menggunakan jenis penelitian yuridis normatif sebagai suatu penelitian yang memiliki fokus terhadap analisis bahan hukum berupa segala jenis peraturan yang berlaku di Indonesia sebagai bahan acuan utama dalam penelitian tersebut. ${ }^{10}$ Pendekatan yang dipergunakan pada penelitian ini yaitu statute approach atau pendekatan peraturan perundang-undangan yang merupakan penelitian yang berfokus pada pengkajian peraturan perundang-undangan terkait dengan isu hukum pada

7 Kornelius Benuf, “Urgensi Kebijakan Perlindungan Hukum Terhadap Konsumen Fintech Peer To Peer Lending Akibat Penyebaran Covid-19", Jurnal RechsVinding, 9, No. 2, (2020): 1.

8 Fajrina Eka Wulandari, Peer To Peer Lending Dalam POJK, PBI Dan Fatwa DSN MUI, Jurnal Hukum Islam Ahkam, 6, No. 2, (2018).

9 Cheyzsa Mega Andhini S.P, “Problematika Hukum Pada Peer To Peer Lending Di Indonesia Dalam Perspektif Hukum Persaingan Usaha", Jurist-Diction, 2, No. 6, (2019): 2655-8297

10 Soekanto, S. (2010), Pengantar Penelitian Hukum, Jakarta: UII Press, h. 201. 
penelitian ini. Adapun sumber bahan hukumnya antara lain bahan hukum primer, sekunder, dan juga tersier. Penulisan ini memiliki sifat deskriptif-analisis yaitu memberi gambaran terhadap permasalahan pada penelitian ini serta melakukan analisis terhadap peraturan hukum terkait untuk memberikan jawab atas permasalahan yang dirumuskan.

\section{Hasil dan Pembahasan}

\subsection{Hubungan Hukum Para Pihak Pada Sistem Peer to Peer (P2P) Lending}

Layanan pinjam meminjam uang dengan sarana teknologi atau lebih dikenal dengan P2P Lending merupakan bentuk nyata munculnya industri 4.0 di Indonesia. Perusahaan ini merupakan digitalisasi dari layanan jasa keuangan konvensional khususnya dalam pengumpulan serta penyaluran pinjaman kepada masyarakat.11 Hingga Februari 2020 telah berkembang 161 institusi yang menyediakan P2P Lending. ${ }^{12}$ Banyaknya jumlah konsumen perusahaan tersebut serta besarnya jumlah pinjaman yang disalurkan melalui lembaga yang menangani $P 2 P$ Lending di Indonesia mengindikasikan bahwa banyak masyarakat yang mempergunakan lembaga jasa keuangan digital di Indonesia, khususnya sebagai konsumen lembaga yang melayani P2P Lending. Hal ini memberikan pengaruh yang positif terhadap pertumbuhan ekonomi Indonesia. Dampak positif adanya sistem P2P Lending sangat dirasakan oleh pelaku UMKM, karena dengan adanya P2P Lending menyebabkan adanya kemudahan dalam mendapatkan modal usaha serta segala kesulitan keuangan menjadi lebih mudah teratasi. ${ }^{13}$

Definisi penyelenggara layanan pinjam dan meminjam uang dengan sarana teknologi di tegaskan dalam POJK No. 77/POJK.01-2016 yaitu pada ketentuan Pasal 1 angka 6. Dalam aturan tersebut penyelenggara layanan pinjam meminjam uang berbasis teknologi informasi merupakan badan hukum Indonesia yang menangani, melakukan pengelolaan serta melakukan pelayanan pinjam meminjam uang dengan teknologi. Bentuk badan hukum yang menyelenggarakan layanan ini bisa berbentuk Perseroan Terbatas (PT) ataupun koperasi. Perusahaan yang menyelenggarakan P2P Lending wajib berbentuk badan hukum, sebab penyelenggaraan $P 2 P$ Lending tidak bisa dilaksanakan secara individu maupun dalam aktivitas usaha yang berbentuk non-badan hukum seperti CV, Firma, atau juga Maatschap. Dilihat dari sisi yuridis, badan hukum mempunyai posisi yang lebih baik dibanding perusahaan tidak berbadan hukum, badan hukum adalah subjek ataupun pendukung hak serta kewajiban yang bisa bertanggung jawab atas nama badan hukum itu.

Berdasarkan pasal 2 POJK No. 77/POJK.01-2016 dapat kita lihat bahwa yayasan dan badan hukum lain tidak bisa melaksanakan aktivitas peer to peer lending. Hanya perusahaan yang berbentuk PT dan Koperasi yang mampu menyelenggarakan P2P Lending karena sudah mendapat pengesahan oleh Kemenkumham ataupun Kementerian Koperasi. Syarat penyelenggara yang harus berbentuk PT ataupun koperasi telah disesuaikan dengan tujuan kepastian hukum terhadap setiap pihak yang

11 Purwandini, D. A., dkk, Komunukasi Korporasi Pada Era Industri 4.0, Jurnal Ilmu Sosial, 17(1), h. 59.

12 Anonim, Penyelenggara Fintech Terdaftar dan Berizin di OJK per 19 Februari 2020. https://www.ojk.go.id/id/, diakses pada 15 November 2020

13 Musdalifa, I, dkk, (2018), Peran Fintech dalam Meningkatkan Keuangan Inklusif pada UMKM di Indonesia (Pendekatan Keuangan Syariah), Jurnal Masharif al-Syariah:Jurnal Ekonomi dan Perbankan Syariah, 3(1), h.8. 
melakukan aktivitas bisnis $P 2 P$ lending mengingat aktivitas usahanya berorientasi pada keuntungan serta melibatkan banyak pihak.

Bank Indonesia dan OJK adalah dua lembaga yang mengatur dan mengawasi pelaksanaan P2P Lending di masyarakat. Masing-masing lembaga dimaksud mempunya peranan sebagai berikut :

1. Bank Indonesia; Pasal 24 POJK No. 77/POJK.01-2016 mengatur jika penyelenggara harus mempergunakan escrow account serta virtual account dalam rangka layanan pinjam dan meminjamkan uang dengan perantara teknologi. Lain daripada hal tersebut, pihak penyelenggara harus pula melakukan penyediaan virtual account untuk tiap pemberi pinjaman serta dalam rangka melunasi pinjaman, pihak yang menerima pinjaman melaksanakan pembayaran dengan escrow account pihak penyelenggara untuk dilanjutkan ke virtual account pihak yang memberi pinjaman. Escrow Account sendiri merupakan rekening giro di Bank atas nama pihak penyelenggara yang adalah titipan serta dipergunakan dalam hal tertentu yakni menerima serta mengeluarkan dana dari serta pada pengguna jasa penyelenggara pinjam dan meminjamkan uang berbasis teknologi. Selanjutnya pada Penjelasan Pasal 24 menyebutkan jika tujuan kewajiban mempergunakan virtual account serta escrow account untuk menyelenggarakan aktivitas layanan pinjam dan meminjamkan uang melalui perantara teknologi yakni larangan bagi pihak yang menyelenggarakan untuk menghimpun dana masyarakat dengan rekening pihak yang menyelenggarakan.

2. Selanjutnya adalah OJK; yaitu lembaga mandiri yang memiliki fungsi, tugas maupun kewenangan dalam hal mengatur, mengawasi, memeriksa, serta melakukan penyidikan sebagaimana dimaksud pada UU No,UU 21-2011 tentang OJK. OJK dalam sistem pinjam meminjamkan uang dengan teknologi ini melaksanakan tindakan sebagai pihak yang memberikan izin dalam mengajukan pendaftaran serta pemberian izin dalam menyelenggarakan sistem dan sebagai pihak yang wajib mendapat laporan atas proses berlangsungnya sistem pinjam meminjamkan uang dengan perantara teknologi informasi. Izin penyelenggaraan merupakan syarat agar bisnis $P 2 P$ Lending dianggap sebagai transaksi yang legal, dimana hal ini juga mempengaruhi omzet dan keuntungan yang didapatkan. ${ }^{14}$

Pihak-pihak yang terlibat dalam P2P Lending sesuai dengan POJK No. 77/POJK.01-2016 adalah :

1. Penyelenggara $P 2 P$ Lending; sesuai ketentuan pasal 1 angka 6 merupakan pihak penyedia sarana (marketplace) yang mempertemukan pihak pemberi pinjaman dan pihak penerima pinjaman. Merupakan badan hukum Indonesia yang berbentuk Perusahaan Terbatas (PT) atau Koperasi.

2. Pemberi pinjaman; sesuai dengan ketentuan pasal 1 angka 8 merupakan orang, badan hukum, dan/atau badan usaha yang memiliki piutang dikarenakan kontrak layanan pinjam meminjam uang dengan teknologi. Selanjutnya disebutkan pula jika pihak yang memberi pinjaman bisa dari dalam dan/atau luar negeri. Pihak yang memberi pinjaman meliputi WNI, WNA, badan hukum Indonesia, asing, dan/atau lembaga internasional.

14 Candika Radita Putri, “Tanggung Gugat Penyelenggara Peer To Peer Lending Jika Penerima Pinjaman Melakukan Wanprestasi", Juris-Diction, 1, No. 2, (2018): 470-471 
3. Penerima pinjaman; diatur pada Pasal 1 yakni orang dan/atau badan hukum yang memiliki utang dikarenakan kontrak pinjam meminjam uang dengan perantara teknologi. Selanjutnya, Pasal 15 mengatur jika pihak yang menerima pinjaman pada sistem peer to peer lending wajib berasal serta domisili dari NKRI. Pihak yang menerima pinjaman bisa berasal dari orang perseorangan WNI ataupun badan hukum Indonesia.

Sistem P2P Lending ini adalah sebuah sebuah platform teknologi yang mempertemukan pihak peminjam yaitu pihak yang memerlukan bantuan modal usaha dengan pihak yang memberi pinjaman secara digital. P2P Lending memberi peluang terdapatnya pengembalian yang bersaing meski mempergunakan modal yang kecil terhadap pihak yang memberi pinjaman. Sistem ini pada dasarnya adalah esensi inklusi keuangan, dapat memberi peluang bagi segmen baru dalam dunia ekonomi, utamanya pada masyarakat luas yang belum dijangkau institusi keuangan yang terdapat di Indonesia. ${ }^{15}$

Layanan P2P Lending yang dikelola oleh penyelenggara dapat memberikan penawaran kepada masyarakat guna melakukan investasi dengan mengambil kedudukan sebagai pemberi pinjaman. Apabila calon pemberi pinjaman memiliki minat dalam memberi pinjaman dengan sistem P2P lending, maka pihak yang memberi pinjaman serta pihak yang penyelenggara akan melakukan kesepakatan kontrak tertentu. Berdasarkan Pasal 18 POJK No. 77/POJK.01/2016 terdapat dua macam perjanjian untuk dapat terlaksananya P2P Lending, yaitu :

1. Perjanjian yang dilakukan oleh Penyelenggara dengan Pemberi Pinjaman.

2. Perjanjian yang dilakukan oleh Pemberi Pinjaman dengan Penerima Pinjaman

Antara pihak penyelenggara, pihak pemberi pinjaman serta pihak penerima pinjaman memiliki hubungan hukum yang lahir dari suatu kontrak yang diwujudkan dalam bentuk dokumen elektronik antara kedua belah pihak sebagaimana tercantum pada Pasal 9 angkat (1) POJK No. 77/POJK.01/2016. Selanjutnya dalam Pasal 19 ayat (2) menentukan bahwa perjanjian ini harus memuat nomor maupun tanggal perjanjian termasuk memuat proses penyelesaian apabila penyelenggara tidak lagi melakukan aktivitas operasionalnya.

Dibandingkan dengan sistem perbankan, hubungan antara nasabah yang menyimpan dana dengan bank secara yuridis formal didasari pada perjanjian nasabah yang menyimpan dana dengan bank. Simpanan merupakan dana yang dipercayakan oleh masyarakat kepada bank berdasarkan kontrak penyimpanan dana berbentuk deposito (berjangka), giro, tabungan, deposito dan/atau bentuk lain yang dianggap sama. ${ }^{16}$

Jika ditelisik lebih lanjut mengenai bentuk perjanjian bernama pada KUHPerdata, maka ditemui beberapa kontrak yang bentuknya mendekati kontrak penyimpanan (simpanan) dana bank tersebut. Terkait perjanjian penitipan pada Pasal 1694 KUHPerdata menyebutkan penitipan terjadi jika seseorang mendapatkan suatu barang oleh orang yang lain, namun syaratnya ia akan melakukan penyimpanan serta melakukan pengembalian ke bentuk asalnya. Akan tetapi kontrak penyimpanan dana di bank tidak sepenuhnya mirip dengan lembaga penitipan, untuk itu dana tersebbut

15 Wijaya, Reynold, (2016), P2P Lending Sebagai Wujud Baru Inklusi Keuangan, https://money.kompas.com. Diakses pada 18 November 2020.

16 Yunita, Maria Astri, (2016), Praktik Bank Gelap, https://www.hukumonline.com. Diakses pada 18 November 2020. 
akan dipergunakan bank dalam mengoperasikan aktivitas bank dan akan dilakukan pengembalian oleh bank pada nasabah yang menyimpan beserta seluruh bunga.

Di lain sisi, perjanjian penyimpanan dana dapat dipersamakan pula dengan perjanjian pinjam dan meminjam uang sebagaimana tercantum dalam KUHPerdata yang mana bank sebagai pihak yang menerima pinjaman di ijinkan mempergunakan dana itu serta menyatakan sanggup untuk melakukan pembayaran bunga. Gazali menyebut bahwa hubungan hukum antara bank serta nasabah didasari pada pemberian kuasa (lastgeving) seperti yang tercantum pada Pasal 1792 KUHPerdata. Selanjutnya nasabah penyimpan dana memberi kuasa pada bank dalam melakukan pemanfaatan uang yang dipercayakan dalam melaksanakan aktivitas usaha perbankan. ${ }^{17}$ Akan tetapi Sutan Remy Sjahdeni tidak sependapat dengan pendapat yang menyatakan bahwa hubungan hukum antara bank dengan nasabah yang melakukan penyimpanan dana dianggap sebagai hubungan pemberian kuasa. Hal itu didasari alasan bahwa apabila hubungan nasabah yang menyimpan dana dengan bank didasarkan pada pemberian kuasa, maka bank sebagai pihak yang menerima kuasa tidak dibenarkan untuk mempergunakan uang nasabah bagi kebutuhannya yaitu menyalurkan kembali dalam bentuk kredit pada pihak ketiga.18 Sebagai penghubung baik bagi pemberi pinjaman maupun peminjam, perusahaan yang menyediakan pelayanan tersebut mempergunakan data pribadi untuk mengetahui nasabah ataupun yang diketahui sebagai Know Your Customer (KYC), memberikan penilaian layak atau tidaknya pihak yang meminjam, dan memberikan layanan pada semua yang mempergunakan. Perusahaan penyedia layanan tersebut akan melaksanakan verifikasi data terhadap pemberi pinjaman, melakukan seleksi pinjaman dengan credit scoring, memberikan pengaturan alur biaya pihak-pihak yang meminjam serta pihak yang memberi pinjaman, dan melaksanakan pengawasan. ${ }^{19}$

Hubungan hukum antara bank dan nasabah penyimpan dana tidak dapat digolongkan kedalam perjanjian bernama sebagaimana yang terdapat pada KUHPerdata, namun digolongkan sebagai hubungan hukum yang timbul karena perjanjian tidak bernama (innominaat contractem). Ini berarti hubungan hukum antara bank dengan nasabah yang menyimpan dana tidak dapat digolongkan sebagai perjanjian antara penitipan (uang), ataupun perjanjian pemberian kuasa, serta tidak bisa dikatakan sebagai perjanjian pinjam dan meminjam uang. UU No. 10-1988 tentang Perbankan (UU Perbankan) sudah melakukan konstruksi hubungan hukum pada bank maupun nasabah yang menyimpan dan berbentuk perjanjian penyimpanan dan yang mempunyai ciri tertentu. ${ }^{20}$

Dengan demikian hubungan hukum antara para pihak dalam P2P Lending tidak dapat dipersamakan dengan hubungan hukum antara bank, nasabah penyimpan dana serta pihak peminjam dalam sistem perbankan. Hubungan hukum antara para pihak dalam pelaksanaan P2P Lending adalah hubungan yang bersifat kontraktual yang lahir dari perjanjian yang dibuat antara mereka yaitu perjanjian antara pihak penyelenggara

17 Gazali, Djoni S., dkk, (2012), Hukum Perbankan, Jakarta: Sinar Grafika, h. 245-249.

18 Ibid, h. 250.

19 Yogantara, Pande S., and Putu Edgar Tanaya. "Penerapan Prinsip Mengenal Nasabah dalam Perdagangan Berjangka Komoditi untuk Mendukung Penanggulangan dan Pemberantasan Tindak Pidana Pencucian Uang (Studi di PT. Monex Investindo Future dan PT. First State Bali)." Halu Oleo Law Review 2, no. 1 (2018): 315-334.

20 Gazali, Djoni S., dkk, Op.cit. h. 253. 
dengan pihak pemberi pinjaman dan perjanjian antara pihak pemberi pinjaman dengan pihak penerima pinjaman sebagaimana ketentuan Pasal 18 POJK No. 77/POJK.01/2016.

\subsection{Pengaturan Penyelesaian Sengketa Pada Sistem Peer to Peer (P2P) Lending}

Pada latar belakang telah disebutkan bahwa OJK telah menerbitkan dua peraturan yang memiliki kaitan dengan P2P Lending, yaitu POJK Nomor 77/POJK.01-2016 dan SOJK Nomor 18/SEOJK.01-2017. Pengaturan dan pengawasan bisnis memiliki kaitan dengan pinjam dan meminjam dengan perantara teknologi informasi juga harus dilakukan berdasar UU Nomor 21-2011 tentang OJK; UU Nomor 19-2016 tentang Perubahan Atas UU Nomor 11-2008 tentang ITE ; UU Nomor 8-1999 tentang Pelindungan Konsumen; UU Nomor 7-2014 tentang Perdagangan; UU Nomor 8-2010 tentang Tindak Pidana Pencucian Uang; UU Nomor 40-2007 tentan PT; UU Nomor 251992 tentang Perkoperasian; UU Nomor 30-1999 tentang Arbitrase dan APS; KUHPerdata, juga peraturan terkait lainnya.

Diperlukan adanya perlindungan atas hak-hak konsumen dalam transaksi elektronik yaitu sampai seberapa jauh regulasi terkait sistem pengawasan yang dilakukan pemerintah terhadap perusahaan penyelenggara fintech itu sendiri. ${ }^{21}$ Perlindungan konsumen pada bisnis dengan perantara transaksi elektronik juga diatur pada PP No. 82 Tahun 2012 tentang Penyelenggaraan Sistem dan Transaksi Elektronik (PSTE). Pasal 49 dalam PP ini menyebutkan jika pelaku usaha harus melaksanakan penyediaan informasi yang benar serta lengkap memiliki kaitan dengan produsen, syarat kontrak serta produk yang dilakukan penawaran apabila memberikan penawaran produk dengan sistem elektronik; harus memberi informasi secara jelas mengenai penawaran kontrak ataupun iklan; harus memberi jangka waktu pada pihak yang membeli untuk melakukan pengembalian barang yang dilakukan pengiriman jika tidak selaras kontrak ataupun adanya cacat tersembunyi; harus memberikan penyampaian informasi tentang benda yang sudah dilakukan pengiiriman; pelaku usaha tidak bisa memberikan beban pada konsumen tentang kewajiban melakukan pembayaran barang yang dikirim tanpa dasar perjanjian.

Namun, peraturan perundang- undangan tersebut belum mengatur mengenai penyelesaian sengketa apabila pihak penerima pinjaman mengalami gagal bayar ataupun tidak dapat melakukan pembayaran pada pinjam meminjam uang dengan platform P2P Lending. Perlindungan Konsumen Sektor Jasa Keuangan yang diatur pada POJK No. 1/POJK.07-2013 belum mencakup perlindungan hukum mengenai hal-hal yang terkait bisnis $P 2 P$ Lending, hal itu dikarenakan oleh belum terdapatnya pengaturan mengenai P2P Lending pada peraturan perlindungan konsumen sektor jasa keuangan. Saat ini jika terdapat permasalahan mengenai transaksi dagang atau bisnis dengan sistem elektronik, pihak yang menghadapi permasalahan bisa melakukan penyelesaian sengketa dengan jalan pengadilan ataupun melalui proses penyelesaian permasalahan lainnya. Proses penyelesaian sengketa dapat dilakukan melalui cara negosiasi, konsultasi, mediasi, konsiliasi, ataupun arbitrase sebagaimana ketentuan dalam peraturan perundang-undangan. ${ }^{22}$

Sengketa perdata dapat terjadi dalam bisnis pinjam meminjam uang dengan $P 2 P$ Lending antar pihak yang memberi pinjaman maupun pihak yang menerima pinjaman.

21 Nuzul Rahmayani, "Tinjauan Hukum Perlindungan Konsumen Terkait Pengawasan Perusahaan Berbasis Financial Technologi di Indonesia", Pagaruyung Law Journal, 2, No. 1, (2018): 39

22 Pasal 65 ayat (5) UU No. 7/2014 tentang Perdagangan beserta penjelasannya. 
Sengketa biasanya muncul karena adanya ketidaktaatan terhadap kontrak yang telah mencapai kata sepakat oleh para pihak. Penyelesaian sengketa bisnis pinjam dan meminjam uang dengan sistem $P 2 P$ lending bisa diselesaikan melalui jalur litigasi maupun non-litigasi. Para pelaku bisnis lebih banyak mempergunakan penyelesaian sengketa secara non-litigasi dibanding litigasi. Gugatan perdata dengan jalan pengadilan menghabiskan waktu lebih banyak, hal ini dikarenakan putusan Pengadilan Negeri dapat dilakukan banding ke Pengadilan Tinggi maupun kasasi ke Mahkamah Agung. Itulah penyebab pelaku bisnis sering mempergunakan jalur non-litigasi dengan jalan Alternatif Penyelesaian Sengketa. ${ }^{23}$

OJK sudah mengeluarkan POJK No. 1/ POJK.07-2014 tentang Lembaga Alternatif Penyelesaian Sengketa di Sektor Jasa Keuangan. POJK itu dibarengi terbitnya Keputusan OJK nomor Kep-01/D.07/2016 yang didalmnya berisi pengesahan terhadap terbentuknya enam lembaga Alternatif Penyelesaian Sengketa (APS), yakni LAPSPI, BAPMI, BMAI, BAMPPI, BMPPI, dan BMDP. Pelaksanaan peraturan tersebut di atas belum terlaksana dengan baik sehingga dipandang penting adanya ketentuan yang tepat dikarenakan ketentuan yang telah dikeluarkan belum memadai. ${ }^{24}$ Syarat yang harus dipenuhi agar sengketa dapat diselesaikan melalui Lembaga APS, yaitu haruslah merupakan persengketaan perdata yang muncul antar pihak-pihak berhubungan dengan aktivitas di sektor industri jasa keuangan; adanya kata sepakat antar pihakpihak yang memiliki sengketa jika sengketa akan diselesaikan dengan perantara Lembaga APS yang berkaitan; adanya permohonan tertulis dari pihak yang memiliki sengketa pada Lembaga APS; sengketa itu bukanlah perkara pidana; sengketa tersebut tidak terkait pelanggaran administratif.

Penyelesaian sengketa bisnis pinjam meminjam uang berbasis teknologi informasi yang diselesaikan melalui Lembaga APS Konvensional merupakan suatu kekeliruan. Hal ini dikarenakan oleh, usaha pinjam meminjam uang dengan perantara teknologi informasi masuk kedalam golongan bisnis online yang aktivitasnya dilaksanakan via internet, dengan demikian memerlukan alur penyelesaian permasalahan yang lebih cepat, mudah, serta terjangkau. Untuk itu perlu dibentuk Lembaga APS online oleh OJK, yang khusus memberikan penanganan permasalahan bisnis pinjam meminjam uang dengan perantara teknologi informasi. Pada Pasal 29 huruf e POJK nomor 77/POJK.01/2016 pula memberikan amanat penyelesaian sengketa pengguna wajib dilaksanakan dengan sederhana, cepat, serta biaya terjangkau.

Usaha pinjam meminjam uang dengan perantara teknologi atau yang dikenal dengan P2P Lending jika penyelesaian sengketanya dilakukan melalui APS sebetulnya bisa dilaksanakan dengan mempergunakan model Penyelesaian Sengketa Daring (PSD) yang istilah lainnya yaitu Online Dispute Resolution (ODR). Dalam hal ini OJK wajib untuk lebih dulu mengeluarkan Peraturan OJK sebagai landasan dibentuknya Lembaga PSD. Sehingga seluruh rangkaian penyelesaian sengketa dilaksanakan dengan perantara internet dan para pihak tidak harus bertemu secara langsung. Pembentukan Lembaga PSD dapat didasari dengan UU ITE. Hal ini dikarenakan seluruh informasi serta data elektronik era ini telah bisa digunakan sebagai bukti hukum.

23 Manuasa Saragi, "Litigasi Dan Non Litigasi Untuk Penyelesaian Sengketa Bisnis Dalam Rangka Pengembangan Investasi Di Indonesia", E-Journal Graduate Unpar, 1, No. 2, (2014): 64.

24 Agus Priyonggojati, "Perlindungan Hukum Terhadap Penerima Pinjaman Dalam Penyelenggaraan Financial Technology Berbasis Peer To Peer Lending" Jurnal USM Law Review 2, No. 2, (2019); 173. 
Landasan yuridis dibentuknya PSD tercantum pada UU ITE yaitu pada ketentuan Pasal 41 lengkap dengan penjelasannya. Masyarakat bisa memiliki peran dalam memanfaatkan teknologi informasi dengan penggunaan maupun penyelenggaraan sistem elektronik serta transaksi elektronik berdasar atas UU ITE. Peran masyarakat bisa diselenggarakan dengan perantara lembaga yang dibentuk masyarakat dalam hal ITE yang bisa mempunyai fungsi konsultasi maupun mediasi. Secara tidak langsung PSD pula dilakukan pengaturan pada Pasal 28 ayat (4) dan (5) UU ITE. Setiap pihak mempunyai wewenang melakukan penetapan forum pengadilan, arbitrase ataupun lembaga penyelesaian sengketa alternatif lain yang memiliki wewenang melakukan penanganan sengketa yang kemungkinan muncul dari transaksi elektronik internasional yang dibuat. Apabila pihak-pihak tidak melaksanakan pilihan forum, secara otomatis penetapan wewenang pengadilan, arbitrase ataupun lembaga penyelesaian sengketa alternatif lain didasari pada asas Hukum Perdata Internasional. PSD ataupun ODR merupakan penyelesaian sengketa alternatif yang harmonis dengan Hukum Perdata Internasional yang sudah diberikan pengakuan oleh PBB.

\section{Kesimpulan}

Hubungan hukum antara para pihak dalam P2P Lending yakni pihak penyelenggara, pihak yang memberi pinjaman serta pihak yang menerima pinjaman adalah hubungan yang bersifat kontraktual sebagaimana dalam ketentuan Pasal 18 POJK No. 77/POJK.01/2016. Hubungan yang bersifat kontraktual tersebut lahir dari perjanjian yang dibuat antara pihak penyelenggara dengan pihak yang memberi pijaman dan perjanjian yang dibuat antara pihak yang memberi pinjaman dengan pihak yang menerima pinjaman. Penyelesaian sengketa pada sistem P2P Lending dapat dilaksanakan melalui pengadilan maupun melalui alternatif penyelesaian sengketa. Akan tetapi sistem P2P Lending yang berbasis online memerlukan proses penyelesaian sengketa yang lebih cepat, mudah, serta terjangkau, sehingga perlu dibuat Lembaga APS online yang khusus melaksanakan penanganan sengketa bisnis pinjam meminjam uang dengan perantara teknologi informasi.

\section{DAFTAR PUSTAKA}

\section{Buku}

Gazali, Djoni S., dkk, Hukum Perbankan, Jakarta: Sinar Grafika, (2012).

Serfiyani, Cita Yustisia, dkk, Bisnis Online dan Transaksi Elektronik, Jakarta: PT. Gramedia Pustaka Utama. (2013).

Soekanto, S. Pengantar Penelitian Hukum. Jakarta : UII Press, (2010).

\section{Jurnal}

Agus Priyonggojati, "Perlindungan Hukum Terhadap Penerima Pinjaman Dalam Penyelenggaraan Financial Technology Berbasis Peer To Peer Lending" Jurnal USM Law Review 2, No. 2, (2019)

Candika Radita Putri, “Tanggung Gugat Penyelenggara Peer To Peer Lending Jika Penerima Pinjaman Melakukan Wanprestasi", Juris-Diction, 1, No. 2, (2018)

Cheyzsa Mega Andhini S.P, "Problematika Hukum Pada Peer To Peer Lending Di Indonesia Dalam Perspektif Hukum Persaingan Usaha", Jurist-Diction, 2, No. 6, (2019): 2655-8297

Ernama Santi, Budiharto, Hendro Saptono, "Pengawasan Otoritas Jasa Keuangan Terhadap Financial Technologi (Peraturan Otoritas Jasa Keuangan Nomor 77/POJK.01/2016)", Diponegoro Law Journal, 6, No. 3, (2017) 
Fajrina Eka Wulandari, Peer To Peer Lending Dalam POJK, PBI Dan Fatwa DSN MUI, Jurnal Hukum Islam Ahkam, 6, No. 2, (2018)

Hariyani, I., Perlindungan Hukum dan Penyelesaian Sengketa Bisnis Jasa PM-Tekfin, Jurnal Legislasi Indonesia, 14(3), (2018).

Heryucha Romana Tampubolon, "Seluk Beluk Peer To Peer Lending Sebagai Wujud Baru Keuangan Di Indonesia”, Jurnal Bina Mulia Hukum, 3, No. 2, (2019)

Kornelius Benuf, "Urgensi Kebijakan Perlindungan Hukum Terhadap Konsumen Fintech Peer To Peer Lending Akibat Penyebaran Covid-19", Jurnal RechsVinding, 9, No. 2, (2020).

Manuasa Saragi, “Litigasi Dan Non Litigasi Untuk Penyelesaian Sengketa Bisnis Dalam Rangka Pengembangan Investasi Di Indonesia”, E-Journal Graduate Unpar, 1, No. 2, (2014)

Muzdalifa, I., Rahma, I. A., \& Novalia, B. G.. Peran fintech dalam meningkatkan keuangan inklusif pada UMKM di Indonesia (pendekatan keuangan syariah). Jurnal Masharif al-Syariah: Jurnal Ekonomi dan Perbankan Syariah, 3(1), (2018).

Nuzul Rahmayani, “Tinjauan Hukum Perlindungan Konsumen Terkait Pengawasan Perusahaan Berbasis Financial Technologi di Indonesia", Pagaruyung Law Journal, 2, No. 1, (2018).

Purwandini, D. A., \& IRWANSYAH, I. KOMUNIKASI KORPORASI PADA ERA INDUSTRI 4.0. Jurnal Ilmu Sosial, 17(1).

Yogantara, Pande S., and Putu Edgar Tanaya. "Penerapan Prinsip Mengenal Nasabah dalam Perdagangan Berjangka Komoditi untuk Mendukung Penanggulangan dan Pemberantasan Tindak Pidana Pencucian Uang (Studi di PT. Monex Investindo Future dan PT. First State Bali)." Halu Oleo Law Review 2, no. 1 (2018): 315-334.

\section{Peraturan Perundang-Undangan}

Undang-Undang Republik Indonesia Nomor 10 Tahun 1998 tentang Perbankan (LN No. : 182, TLN No. : 3790).

Undang-Undang Republik Indonesia Nomor 7 Tahun 2014 tentang Perdagangan (LN No. : 45 , TLN No. : 5512).

Peraturan Otoritas Jasa Keuangan Nomor 77 /POJK.01/2016 Tentang Layanan Pinjam Meminjam Uang Berbasis Teknologi Informasi.

Surat Edaran Otoritas Jasa Keuangan Nomor 18 /SEOJK.02/2017 Tentang Tata Kelola Dan Manajemen Risiko Teknologi Informasi Pada Layanan Pinjam Meminjam Uang Berbasis Teknologi Informasi.

\section{Internet}

https://money.kompas.com/read/2016/11/26/060000226/.p2p.lending.sebagai.wuju d.baru.inklusi.keuangan?page=all. Diakses pada 18 November 2020.

https://www.hukumonline.com/klinik/detail/ulasan/lt5003cbf860b91/praktikbank-gelap/. Diakses pada 18 November 2020.

https://www.ojk.go.id/id/berita-dan-kegiatan/publikasi/Pages/Penyelenggara-

Fintech-Terdaftar-dan-Berizin-di-OJK-per-19-Februari-2020.aspx. $\quad$ Diakses pada 15 November 2020 